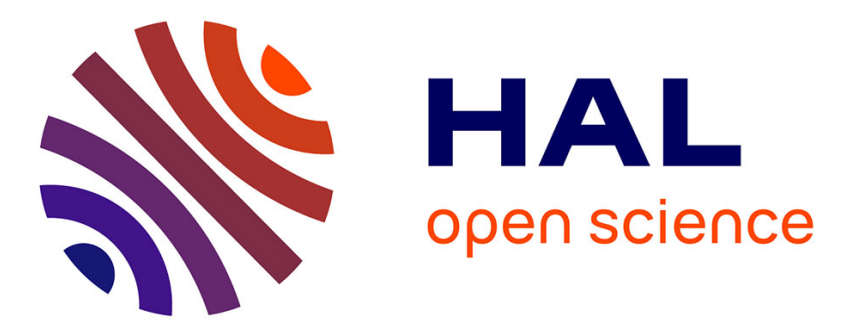

\title{
Impact of maternal age on intrapartum caesarean delivery rate in nulliparas with spontaneous labour
}

Simon Crequit, Diane Korb, Thomas Schmitz, Cécile Morin, Olivier Sibony

\section{To cite this version:}

Simon Crequit, Diane Korb, Thomas Schmitz, Cécile Morin, Olivier Sibony. Impact of maternal age on intrapartum caesarean delivery rate in nulliparas with spontaneous labour. Journal of Gynecology Obstetrics and Human Reproduction, 2019, 48, pp.407 - 411. 10.1016/j.jogoh.2019.02.008 . hal03484953

\section{HAL Id: hal-03484953 https://hal.science/hal-03484953}

Submitted on 20 Dec 2021

HAL is a multi-disciplinary open access archive for the deposit and dissemination of scientific research documents, whether they are published or not. The documents may come from teaching and research institutions in France or abroad, or from public or private research centers.
L'archive ouverte pluridisciplinaire HAL, est destinée au dépôt et à la diffusion de documents scientifiques de niveau recherche, publiés ou non, émanant des établissements d'enseignement et de recherche français ou étrangers, des laboratoires publics ou privés.

\section{(ㄷ)(1) $\$$}

Distributed under a Creative Commons Attribution - NonCommerciall 4.0 International 
Version of Record: https://www.sciencedirect.com/science/article/pii/S2468784718304975

Manuscript_be52d5b2580165d407835b596b63012c

\section{Title}

2 Impact of maternal age on intrapartum caesarean delivery rate in nulliparas with spontaneous

3 labour

\section{$4 \quad$ Author names and affiliations}

5 Simon Crequit ${ }^{1}$, Diane Korb ${ }^{1,2}$, Thomas Schmitz ${ }^{1,2}$, Cécile Morin ${ }^{1}$, Olivier Sibony ${ }^{1}$

$6{ }^{1}$ Department of Gynecology and Obstetrics, Robert Debré University Hospital, AP-HP, Paris, France

$7 \quad{ }^{2}$ INSERM U1153, EPOPé Team, Paris, France

8

\section{Corresponding author}

10 Diane Korb, Department of Obstetrics and Gynecology, Robert Debré Hospital, 48 boulevard

11 Sérurier, 75019 Paris, France, Tel: +33(0)1 400321 66, Fax: +33 (0)1 400324 80, Email:

12 diane.korb@aphp.fr 


\section{Abstract}

Background: The advanced maternal age rate increases in developed countries. Older women have more pre-existing condition than youngest women and develop more frequently obstetrical pathologies responsible for a higher rate of caesarean delivery before labour and labour induction. For aged nulliparous without pathology who experience spontaneous labour, there is few data on the mode of delivery and on physiological labour according to maternal age.

Objective: To compare the intrapartum caesarean delivery rate according to maternal age, for nulliparous with planned vaginal delivery and spontaneous labour at term.

Methods: Retrospective cohort in a single academic institution between January 2000 and June 2017. All nulliparous women with planned vaginal delivery with live singleton in cephalic presentation at and after 37 weeks of gestation with spontaneous labour were included ( $n=10,611)$. Two groups were compared: nulliparous women aged 20 to 34 and nulliparous women aged 35 and over. The main outcome was the intrapartum caesarean delivery rate. A subgroup analysis was performed for nulliparous with more advanced maternal age defined as women over 40.

Results: Among the 10,611 women included in this analysis, 8,993 (84.8\%) were aged 20 to 34 and 1,618 (15.2\%) were aged over 35. From the latter $367(22.7 \%)$ were over 40 years old. The intrapartum caesarean delivery rate was similar between women aged between 20 and 34 and women aged over 35 (10.8\% compared to $8.8 \%$; cOR 0.91, 95\% CI 0.76-1.08; aOR 0.91, 95\% CI 0.76-1.09). The indications of caesarean were similar in both groups. No differences were found between both groups for mean labour duration (430.9 min for the [20-34] years group compared to 428.0 min for the over 35 years group, $\mathrm{p}=0.654)$. The subgroup analysis 
40 Conclusion: For nulliparous at term in spontaneous labour, an advanced maternal age was 41 not associated with an increased intrapartum caesarean delivery rate.

42

\section{$43 \quad$ Keywords}

44 Nulliparous, caesarean delivery, duration of labour, labour outcome, advanced maternal age, 45 trial of labour

46

47

\section{$48 \quad$ Funding sources}

49 This research did not receive any specific grant from funding agencies in the public, 50 commercial, or not-for-profit sectors.

51 
Advanced maternal age has been defined as an age $\geq 35$ years at the time of delivery. The proportion of births in women aged 35 and over has been steadily rising in recent years in developed countries [1-3]. In France it accounted for about 21.3\% of all births in 2016 compared with $15.9 \%$ in 2003 [2]. The increased caesarean rate observed recently has been explained by the increased maternal age. Indeed pregnancy among older women is associated with a variety of adverse obstetric diseases [4-6] partly because these women have preexisting medical conditions. These latter are responsible for a higher rate of planned caesarean before labor and induction of labor. In this population of aged women, the induction of labor has been associated with a high rate of failure and so of caesarean [7]. A biologic plausibility was advanced to explain that: the aged uterus function differently in labor, contributing to labor dysfunction and ultimately to a caesarean delivery [8-10]. Aged parturients constitute a heterogenous group stratified by different obstetrical complications and modes of onset of labour. Indeed, few studies analyzed the physiological labour outcomes for women without pathology requiring a planned caesarean or a labour induction[11,12]. Furthermore, very few studies stratify the risk of caesarean delivery by parity and even fewer studies report whether a trial of labour was attempted[13,14].

Our aim was to compare the intrapartum caesarean delivery rate between nulliparous aged over 35 and nulliparous aged 20 to 34, with planned vaginal delivery and spontaneous labour at term.

Material and methods.

\section{Study population}

Using hospital birth records, we identified all nulliparous delivering at a single academic 
The study was limited to nulliparous women to remove the potential confounding effects of multiparity and previous caesarean section on the risk of caesarean delivery. Nulliparas aged less than 20 were excluded. Women with planned caesarean delivery, preterm labour before 37 weeks of gestation and labour induction were excluded.

This analysis included 10,611 women. Two groups were compared: nulliparous women aged 20 to $34(\mathrm{n}=8,993 ; 84.8 \%)$ and nulliparous women aged over $35(\mathrm{n}=1,618 ; 15.2 \%)$ (Figure 1$)$.

Social and demographic characteristics, pregnancy characteristics, obstetrical, maternal and neonatal outcomes were collected prospectively. All data were prospectively reported in a computerized database at each consultation, during pregnancy, labour and after delivery by health professional including midwives and obstetrician in care of the patient. These data were checked for validity for each parturient in staff during the following day after delivery.

\section{Outcomes}

The main outcome was the intrapartum caesarean delivery rate. It was treated as a binary variable. Secondary outcomes were total labour duration, and labour phases duration. In agreement with the last recommendation we chose as the latent phase the period between the onset of labour and $6 \mathrm{~cm}$ of cervical dilation, the active phase was between $6 \mathrm{~cm}$ and complete dilation [15]. The second phase was defined as the duration between complete dilation and expulsion. Labour phases duration were analysed regardless of the mode of delivery (caesarean or vaginal delivery) and then specifically for vaginal deliveries. These different phases were determined from the partographs. Partographs were prospectively filled during labour by practitioners. Once the labour started, the partograph started, and all women were examined every hour or before if progress dilatation was suspected, if women was painful, and in cases of abnormalities on CTG. Cardiotocography, with continuous electronic fetal heart rate and uterine contraction registration, was applied to all women. The whole 
management of each labor and delivery was undertaken by the physician on duty. Oxytocin was administered in case of labor arrest with a lack of uterine contractility. Caesarean section for arrest of labor was indicated in case of stagnation of cervical dilation despite ruptured membranes and a correct uterine activity in term of frequency and intensity, without a threshold of duration being predetermined. In case of abnormal fetal heart rate, a second-line exam was not systematic to decide a caesarean, and its indication was left to the obstetrician in care of the patient. During the study period, the obstetrical practices have not been modified. In this maternity, maternal age is not an element considered in the management of labor and in the decision of caesarean section.

\section{Subgroup analysis}

In subgroup analysis, we focused specifically on the older part of the study population and defined more advanced maternal age group as women aged at least 40 . This analysis included 367 women.

\section{Statistical analysis}

We compared the characteristics of the women, pregnancies, labors and neonates, according to maternal age, based on $\mathrm{Chi}^{2}$ or Fisher exact tests for categorical variables and Student's or Wilcoxon rank sum tests for quantitative variables, as appropriate. To assess the relation between maternal age and the caesarean delivery rate, while controlling for confounding by indication, we first used multivariate logistic regression to estimate OR and 95\% CI to adjust for prognostic covariates. Potential confounders determined from the previous literature included: body mass index before pregnancy (continuous variable), gestational diabetes (binary variable), gestational hypertensive pathologies (binary variable), gestational age at delivery (continuous variable), and birth weight (continuous variable). 
127 All tests were two-sided with $P$-values $\leq 0.05$ defined as statistically significant. STATA 13

128

129

130

131

132

133

134

135

136

137

138

139

140

141

142

143

144

145

146

147

148

149

150

151

software (StataCorp LP, College Station, TX) was used for the descriptive and multivariate analyses.

\section{Results}

Our study population included 10,611 women: 8,993 (84.8\%) aged 20 to 34 and 1,618 (15.2\%) aged over 35. In the [20-34] years old group, 2,066 (23.0\%) were aged 20 to 24, $3,688(41.0 \%)$ were aged 25 to $29,3,239(36.0 \%)$ were aged 30 to 34 . In the $\geq 35$ years old group, 1,251 (77.3\%) were aged 35 to 39,338 (20.9\%) were aged 40 to 44 and $29(1.8 \%)$ were aged 45 or more. Women aged $\geq 35$ years old, compared with women aged 20 to 34 were more often obese, smokers and had more pre-existing hypertension, pregnancies obtained by in vitro fertilisation, gestational diabetes and gestational hypertensive pathologies (Table 1). They also gave birth at a later gestational age. Both groups had similar labour characteristics.

The caesarean delivery rate was $10.8 \%$ in the [20-34] years old group and $8.8 \%$ in the $\geq 35$ years old group (cOR $0.91,95 \%$ CI $0.76-1.08$ ), indications and cervical dilation at intervention were similar in both groups (Table 2). After adjustment for confounders, no association was found between maternal age and caesarean delivery rate (aOR 0.91, 95\% CI 0.76-1.09).

Labour mean duration was $430.9 \mathrm{~min}$ in the [20-34] years old group and $428.0 \mathrm{~min}$ in the $\geq 35$ years old group $(\mathrm{p}=0.654)$ (Table 2$)$. The different phases of labour mean duration did not differ between both groups. Similar results were found for the analysis of labour duration for women who gave birth vaginally after exclusion of caesarean delivery.

No differences for maternal and neonatal outcomes were found between both groups (Table 2 and 3). 


\section{Subgroup analysis}

154 The subgroup analysis performed on women aged over 40 yielded similar results: the 155 caesarean delivery rate was similar in both groups: $10.8 \%$ in [20-34] years group compared to $15610.3 \%$ in $\geq 40$ years group (cOR $0.96,95 \%$ CI $0.68-1.35$; aOR $0.94,95 \%$ CI $0.66-1.34$ ) as well as labour duration (430.8 min compared to 426.9 min; $\mathrm{p}=0.733$; Appendix A.1 to A.5).

\section{Discussion}

\section{Main finding}

This study found a similar caesarean delivery rate between women aged 20 to 34 and women with advanced maternal age defined by an age over 35 years old in case of spontaneous labour at term. Moreover, labour outcomes were similar in the two groups.

\section{Interpretation}

Despite the exclusion of women with planned caesarean section or labour induction due to pathologies, like in previous studies, we found that women over 35 years old had more pregnancy complications than youngest women: macrosomia, gestational diabetes, gestational hypertensive pathologies and prolonged pregnancies [16]. Therefore, our selection criteria consisting in excluding caesarean section before labour and labour induction did not over-select a low-risk population of nulliparous with advanced maternal age.

172 Concerning the management of labour, our two groups displayed the same characteristics, particularly for epidural use and oxytocin use, which confirms a management independent of maternal age. This resulted in a similar rate of intrapartum caesarean delivery in the two groups without resorting to more intrapartum intervention. Furthermore, this same rate is obtained despite a low intrapartum caesarean delivery rate in line with goals set by the World 
177 Health Organization [17] and low rates of induction and caesarean before labour for nulliparas with advanced age.

179 It is the first time that no association was found between maternal age and caesarean rate in a low-risk population. It can be explained by the fact that our results were stronger than previous studies in terms of methodological limits. Indeed, to avoid confounding factors we selected a population including nulliparas only to dodge the effect of parity. We excluded labor induction that is a recognized risk factor of caesarean delivery and adjusted for many confounding factors.

Our results are consistent with recent fundamental research on human uterus muscle showing the same trend: two studies on uterine strips collected during planned caesarean delivery has shown no differences between young and older women concerning spontaneous or pharmacologically induced contractility $[18,19]$. Another one demonstrated that uterine muscle efficiency was diminished in older non-pregnant women but was restored during pregnancy probably due to the remaining high hormonal response ability of the aging myometrium [20]. The absence of a change in the contractile function of the uterus with maternal age is supported by the fact that we observe the same caesarean rate at the same dilatation, with a same arrest of labour rate in both groups; as well as the same duration of labour and the same use of oxytocin.

Consequently, the increase in the caesarean delivery rate with maternal age observed in previous studies can be associated with practitioner's behaviour who tend to either diagnose labour dystocia (more frequently or earlier during labour) in aged women or accept these women preference to perform caesarean delivery. Indeed, older nulliparous women have been found to have a more positive attitude towards caesarean section a higher perception of pregnancy risk, even in older women without known risk factors [9]. These considerations are reinforced by the fact that the rate of caesarean delivery observed in our study population 
is lower than the overall rate of caesarean delivery that occurred in the same maternity during the study period, which was about $16-17 \%$. Thus, the increase in the caesarean delivery rate in women with advanced maternal age observed in previous studies is probably due to nonrigorous or uncontrolled indications to perform caesarean section.

\section{Strengths}

Our study has several strengths. The long period data collection allowed the inclusion of a large number of women, which gave a substantial power to highlight a difference between both groups of maternal age if it exists. Attending practitioners prospectively collected the data about the management of the pregnancy, labor and delivery, and these data were ascertained routinely by medical staff the day after the delivery, so that thorough and accurate information was available. We have detailed information about the patients labour. The hospital database allowed us the collection of numerous covariates to address many potential confounding factors in the logistic regression models and to estimate the association between maternal age and caesarean delivery rate with greater precision. This study was limited to nulliparous women to eliminate the confounding effects of multiparity and previous caesarean delivery.

\section{Limitations}

This study is not without limitation. Its retrospective design can limit the generalization of the results, but the characteristics of women and labor are similar to these described in the ENP suggesting a good external validity [2]. Furthermore, the unicentric design of the study allowed having a homogeneous management of the women in the follow-up of the pregnancy and the management of labor and delivery, by a team for whom maternal age is not taken into account in labor management. The sample size did not allow us to study women aged over 40 
as a separate group with good precision, but it is the case for numerous other studies. In addition, studies which have found an increased risk of caesarean delivery with advanced maternal age have shown a linear increase and an absence of cut-off.

This study was conducted in France, which may limit the external validity of the results for other countries. However, the rate and practices of caesarean delivery in France are similar to those in other high resource countries [21].

\section{Clinical impact}

For aged women, planned vaginal delivery must be encouraged because the rate of success is high. Moreover, maternal and neonatal complications are scares while caesarean delivery is associated with more severe acute maternal morbidity, especially if maternal age is high. Consequently, planned caesarean delivery and induction of labour must be limited to strict medical indications only and the possibility of few or no subsequent pregnancies for these aged women should not contribute to the easy achievement of a caesarean delivery.

These results emphasize that any woman should be managed in a way that results in the best possible outcomes for both mother and baby, irrespective of age. The group of women aged over 35 should be managed during labour as their younger counterparts, with finally the same caesarean delivery rate without compromising the health and wellbeing of mothers and babies.

\section{Disclosure of interest}

The authors declare that they have no competing interest. 


\section{References}

252

253

254

255

256

257

258

259

260

261

262

263

264

265

266

267

268

269

270

271

272

273

[1] Martin JA, Hamilton BE, Osterman MJK. Births in the United States, 2016. NCHS data brief, no 287. Hyattsville, MD: National Center for Health Statistics. 2017. n.d.

[2] Blondel B, Coulm B, Bonnet C, Goffinet F, Le Ray C. Trends in perinatal health in metropolitan France from 1995 to 2016: Results from the French National Perinatal Surveys. J Gynecol Obstet Hum Reprod 2017. doi:10.1016/j.jogoh.2017.09.002.

[3] Office for National Statistics. Live births in England and Wales by characteristics of mother 1, 2011. November 2013. http://www.ons. gov.uk/ons/dcp171778_296157.pdf n.d.

[4] Berkowitz GS, Skovron ML, Lapinski RH, Berkowitz RL. Delayed childbearing and the outcome of pregnancy. N Engl J Med 1990;322:659-64. doi:10.1056/NEJM199003083221004.

[5] Bianco A, Stone J, Lynch L, Lapinski R, Berkowitz G, Berkowitz RL. Pregnancy outcome at age 40 and older. Obstet Gynecol 1996;87:917-22.

[6] Kort DH, Gosselin J, Choi JM, Thornton MH, Cleary-Goldman J, Sauer MV. Pregnancy after age 50: defining risks for mother and child. Am J Perinatol 2012;29:245-50. doi:10.1055/s-0031-1285101.

[7] Ecker JL, Chen KT, Cohen AP, Riley LE, Lieberman ES. Increased risk of cesarean delivery with advancing maternal age: indications and associated factors in nulliparous women. Am J Obstet Gynecol 2001;185:883-7. doi:10.1067/mob.2001.117364.

[8] Crawford BS, Davis J, Harrigill K. Uterine artery atherosclerotic disease: histologic features and clinical correlation. Obstet Gynecol 1997;90:210-5. doi:10.1016/S00297844(97)00225-1. 
[9] Bayrampour H, Heaman M, Duncan KA, Tough S. Comparison of perception of pregnancy risk of nulliparous women of advanced maternal age and younger age. $\mathbf{J}$ Midwifery Womens Health 2012;57:445-53. doi:10.1111/j.1542-2011.2012.00188.x.

[10] Treacy A, Robson M, O’Herlihy C. Dystocia increases with advancing maternal age. Am J Obstet Gynecol 2006;195:760-3. doi:10.1016/j.ajog.2006.05.052.

[11] Klemetti R, Gissler M, Sainio S, Hemminki E. Associations of maternal age with maternity care use and birth outcomes in primiparous women: a comparison of results in 1991 and 2008 in Finland. BJOG Int J Obstet Gynaecol 2014;121:356-62. doi:10.1111/1471-0528.12415.

[12] Vaughan D, Cleary B, Murphy D. Delivery outcomes for nulliparous women at the extremes of maternal age - a cohort study. BJOG Int J Obstet Gynaecol 2014;121:2618. doi:10.1111/1471-0528.12311.

[13] Main DM, Main EK, Moore DH. The relationship between maternal age and uterine dysfunction: A continuous effect throughout reproductive life. Am J Obstet Gynecol 2000;182:1312-20. doi:10.1067/mob.2000.106249.

[14] Ecker JL, Chen KT, Cohen AP, Riley LE, Lieberman ES. Increased risk of cesarean delivery with advancing maternal age: Indications and associated factors in nulliparous women. Am J Obstet Gynecol 2001;185:883-7. doi:10.1067/mob.2001.117364.

[15] Zhang J, Landy HJ, Branch DW, Burkman R, Haberman S, Gregory KD, et al. Contemporary patterns of spontaneous labor with normal neonatal outcomes. Obstet Gynecol 2010;116:1281-7. doi:10.1097/AOG.0b013e3181fdef6e.

[16] Luke B, Brown MB. Elevated risks of pregnancy complications and adverse outcomes with increasing maternal age Hum Reprod 2007;22:1264-72. doi:10.1093/humrep/del522. 
[17] Gibbons L, Belizan JM, Lauer JA, Betran AP, Merialdi M, Althabe F. The global numbers and costs of additionally needed and unnecessary cesarean sections performed per year: overuse as a barrier to universal coverage. Nov. 17, 2010 [cited; 1e32]. Available from: http://www.who. int/healthsystems/topics/financing/healthreport/ 30Csectioncosts.pdf. Accessed May 5, 2015 n.d.

[18] Crankshaw DJ, O’Brien YM, Crosby DA, Morrison JJ. Maternal Age and Contractility of Human Myometrium in Pregnancy. Reprod Sci 2015;22:1229-35. doi:10.1177/1933719115572483.

[19] Smith GC, Cordeaux Y, White IR, Pasupathy D, Missfelder-Lobos H, Pell JP, et al. The effect of delaying childbirth on primary cesarean section rates. PLoS Med 2008;5:e144.

[20] Arrowsmith S, Robinson H, Noble K, Wray S. What do we know about what happens to myometrial function as women age? J Muscle Res Cell Motil 2012;33:209-17. doi:10.1007/s10974-012-9300-2.

[21] European Perinatal Health Report $2010 \quad$ [Internet]. [http://www.europeristat.com/reports/european-perinatal-health-report-2010.html]. n.d. 


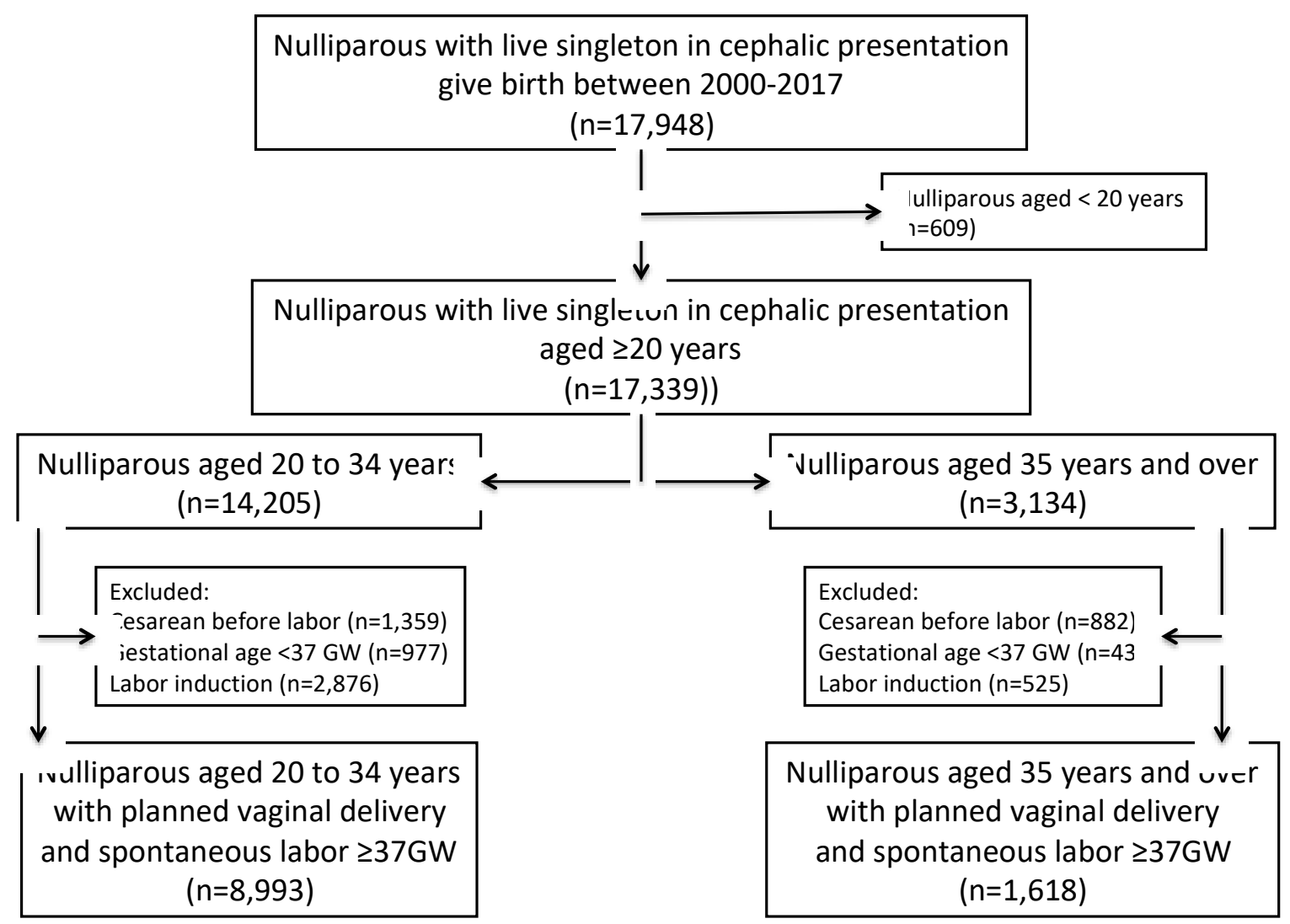




\begin{tabular}{|c|c|c|c|}
\hline & $\begin{array}{c}<35 \text { years } \\
\mathbf{N}=\mathbf{8 9 9 3} \\
\mathrm{n}(\%)\end{array}$ & $\begin{array}{c}\geq 35 \text { years } \\
\mathbf{N}=\mathbf{1 6 1 8} \\
\mathrm{n}(\%)\end{array}$ & $\mathbf{P}$ \\
\hline \multicolumn{4}{|l|}{ Maternal characteristics } \\
\hline Age (years) $($ mean $\pm \mathrm{SD})$ & $28.2 \pm 3.8$ & $38.2 \pm 2.6$ & $<0.0001$ \\
\hline \multicolumn{4}{|l|}{ Body mass index before pregnancy $\left(\mathrm{kg} / \mathrm{m}^{2}\right)$} \\
\hline Mean \pm SD & $22.1 \pm 4.1$ & $22.5 \pm 4.3$ & 0.0002 \\
\hline$<18,5$ & $1149(13.6)$ & $160(10.2)$ & \multirow{4}{*}{0.001} \\
\hline$[18.5-24]$ & $5606(66.2)$ & $1060(67.5)$ & \\
\hline [25-29] & $1232(14.5)$ & $242(15.4)$ & \\
\hline$\geq 30$ & $478(5.6)$ & $108(6.9)$ & \\
\hline Weight gain $(\mathrm{kg})($ mean $\pm \mathrm{SD})$ & $12.7 \pm 5.8$ & $12.00 \pm 5.3$ & $<0.001$ \\
\hline$<9$ & $1224(19.3)$ & $267(21.5)$ & \\
\hline$[9-11]$ & $1394(21.9)$ & $291(23.4)$ & 0.048 \\
\hline$\geq 12$ & $3737(58.8)$ & $685(55.1)$ & \\
\hline Smoker & $1294(14.4)$ & $282(17.4)$ & $<0.001$ \\
\hline Chronic hypertension & $65(0.7)$ & $25(1.5)$ & 0.001 \\
\hline Diabetus mellitus & $70(0.8)$ & $19(1.2)$ & 0.108 \\
\hline \multicolumn{4}{|l|}{ Characteristics of current pregnancy } \\
\hline In vitro fertilisation & $271(3.0)$ & $216(13.4)$ & $<0.001$ \\
\hline Gestational diabetes & $277(3.1)$ & $106(6.5)$ & $<0.001$ \\
\hline Hypertensive gestational diseases & $206(2.3)$ & $62(3.8)$ & $<0.001$ \\
\hline Preterm labour & $649(7.2)$ & $115(7.1)$ & 0.876 \\
\hline Premature rupture of membrane & $82(0.9)$ & $20(1.2)$ & 0.218 \\
\hline Prenatal corticotherapy & $373(4.1)$ & $61(3.8)$ & 0.48 \\
\hline Supected intrauterine growth restriction & $26(0.3)$ & $4(0.25)$ & 0.77 \\
\hline Suspected macrosomia & $546(7.1)$ & $109(7.6)$ & 0.517 \\
\hline \multicolumn{4}{|l|}{ Labor characteristics } \\
\hline \multicolumn{4}{|l|}{ Gestational age at delivery (weeks) } \\
\hline Mean $( \pm$ SD) & $39.9 \pm 1.2$ & $40.0 \pm 1.2$ & $<0.001$ \\
\hline $370 / 7-386 / 7$ & $1859(20.7)$ & $288(17.8)$ & $<0.001$ \\
\hline $390 / 7-406 / 7$ & $5279(58.7)$ & 904 (55.9) & \\
\hline $410 / 7-416 / 7$ & $1583(17.6)$ & $343(21.2)$ & \\
\hline$\geq 420 / 7$ & $272(3.0)$ & $83(5.1)$ & \\
\hline \multicolumn{4}{|l|}{ Cervical dilation at first examination $(\mathrm{cm})$} \\
\hline Mean $( \pm$ SD) & $3.2 \pm 1.4$ & $3.1 \pm 1.4$ & 0.303 \\
\hline Median (Q1-Q3) & $3(2-3)$ & $3(2-3)$ & 0.175 \\
\hline Peridural anesthesia & $7818(86.9)$ & $1432(88.5)$ & 0.082 \\
\hline \multicolumn{4}{|c|}{ Cervical dilation at pose of peridural anesthesia $(\mathrm{cm})$} \\
\hline Mean $( \pm$ SD $)$ & $4.2 \pm 1.8$ & $4.2 \pm 1.8$ & 0.852 \\
\hline Median (Q1-Q3) & $4(3-5)$ & $4(3-5)$ & 0.3 \\
\hline Oxytocin use & $4810(53.5)$ & $874(54.0)$ & 0.693 \\
\hline \multicolumn{4}{|l|}{ Maximal oxytocin dose (UI) } \\
\hline Mean $( \pm$ SD $)$ & $38.3 \pm 24.1$ & $38.5 \pm 23.5$ & 0.855 \\
\hline Median (Q1-Q3) & $30(20-50)$ & $30(20-50)$ & 0.689 \\
\hline
\end{tabular}


Table 2: Delivery characteristics

\begin{tabular}{|c|c|c|c|}
\hline & $\begin{array}{c}<35 \text { years } \\
\mathbf{N}=\mathbf{8 9 9 3} \\
\mathrm{n}(\%)\end{array}$ & $\begin{array}{c}\geq 35 \text { years } \\
\mathbf{N}=1618 \\
\mathrm{n}(\%)\end{array}$ & $\mathbf{P}$ \\
\hline Delivery mode & & & 0.27 \\
\hline Vaginal & $8026(89.2)$ & $1459(90.2)$ & \\
\hline Caesarean section & $967(10.7)$ & $159(9.8)$ & \\
\hline \multicolumn{4}{|l|}{ Caesarian section } \\
\hline Indications & & & 0.896 \\
\hline Abnormal fetal heart rate & $389(40.2)$ & $64(40.3)$ & \\
\hline Arrest of labor & $547(56.6)$ & $91(57.2)$ & \\
\hline Others & $31(3.2)$ & $4(2.5)$ & \\
\hline \multicolumn{4}{|l|}{ Cervical dilation at CS (cm) } \\
\hline Mean $( \pm$ SD $)$ & $6.1 \pm 2.5$ & $6 \pm 2.3$ & 0.642 \\
\hline Median (Q1-Q3) & $6(4-8)$ & $6(4-7)$ & 0.561 \\
\hline \multicolumn{4}{|l|}{ Labor duration (minutes) } \\
\hline \multicolumn{4}{|l|}{ Total labor } \\
\hline Mean $( \pm \mathrm{SD})$ & $430.8 \pm 220.1$ & $428 \pm 212.2$ & 0.654 \\
\hline Median (Q1-Q3) & $422(274-570)$ & $420(284-554)$ & 0.689 \\
\hline \multicolumn{4}{|l|}{ Latent phase } \\
\hline Mean $( \pm \mathrm{SD})$ & $191.9 \pm 131.9$ & $190.2 \pm 130.5$ & 0.651 \\
\hline Median (Q1-Q3) & $182.5(84-275)$ & $180(85-271)$ & 0.611 \\
\hline \multicolumn{4}{|l|}{ Active phase } \\
\hline Mean $( \pm \mathrm{SD})$ & $150.1 \pm 110.4$ & $148.0 \pm 104.8$ & 0.498 \\
\hline Median (Q1-Q3) & $125(70-201)$ & $120(69-198)$ & 0.510 \\
\hline \multicolumn{4}{|l|}{ Second phase } \\
\hline Mean $( \pm \mathrm{SD})$ & $55.3 \pm 57.3$ & $56.35 \pm 57.0$ & 0.510 \\
\hline Median (Q1-Q3) & $40(0-110)$ & $42.8(0-110)$ & 0.445 \\
\hline \multicolumn{4}{|l|}{ Vaginal delivery } \\
\hline \multicolumn{4}{|l|}{ Total labor duration (minutes) } \\
\hline Mean $( \pm$ SD $)$ & $421.6 \pm 213.6$ & $419.5 \pm 209.0$ & 0.723 \\
\hline Median (Q1-Q3) & $414(271-557)$ & $409(277-543)$ & 0.614 \\
\hline \multicolumn{4}{|l|}{ Latent phase duration (minutes) } \\
\hline Mean $( \pm$ SD $)$ & $191.9 \pm 131.9$ & $190.2 \pm 130.5$ & 0.651 \\
\hline Median (Q1-Q3) & $182.5(84-275)$ & $180(85-271)$ & 0.611 \\
\hline \multicolumn{4}{|l|}{ Active phase duration (minutes) } \\
\hline Mean $( \pm$ SD $)$ & $150.1 \pm 110.4$ & $148.0 \pm 104.8$ & 0.498 \\
\hline Median $(\mathrm{Q} 1-\mathrm{Q} 3)$ & $125(70-201)$ & $120(68.5-198)$ & 0.510 \\
\hline \multicolumn{4}{|l|}{ Second phase duration (minutes) } \\
\hline Mean $( \pm S D)$ & $55.3 \pm 57.3$ & $56.3 \pm 57.0$ & 0.510 \\
\hline Median (Q1-Q3) & $40(0-110)$ & $42.8(0-110)$ & 0.457 \\
\hline Operative vaginal delivery & $3368(42.0)$ & $603(41.3)$ & 0.652 \\
\hline Indications & & & 0.101 \\
\hline Abnormal cardiac fotal rate & $1904(57.0)$ & $352(58.9)$ & \\
\hline Slow progression & $1433(42.9)$ & $244(40.8)$ & \\
\hline Other & $2(0.1)$ & $2(0.3)$ & \\
\hline Third or fourth perineal laceration & $23(0.3)$ & $3(0.2)$ & 0.887 \\
\hline
\end{tabular}

Postpartum complications 


\begin{tabular}{lccc} 
Postpartum hemorrhage & $358(4.0)$ & $76(4.7)$ & 0.181 \\
Blood transfusion & $118(1.3)$ & $35(2.2)$ & 0.008 \\
Nalador & $317(3.5)$ & $66(4.1)$ & 0.271 \\
Uterine arteries embolisation & $2(0.02)$ & $1(0.06)$ & 0.383 \\
Vascular ligation & $2(0.02)$ & $1(0.06)$ & 0.383 \\
Compressive uterine sutures & $11(0.1)$ & $5(0.3)$ & 0.075 \\
Hysterectomy & $0(0)$ & $0(0)$ & - \\
\hline
\end{tabular}

SD: standard deviation

Q1-Q3 : first quartile, third quartile

$\mathrm{CS}$ : caesarean section 
Table 3: Neonatal outcomes

\begin{tabular}{|c|c|c|c|}
\hline & $\begin{array}{c}<35 \text { years } \\
\mathbf{N}=\mathbf{8 9 9 3} \\
\mathrm{n}(\%)\end{array}$ & $\begin{array}{c}\geq 35 \text { years } \\
\mathbf{N}=1618 \\
\mathrm{n}(\%)\end{array}$ & $\mathbf{P}$ \\
\hline Gender & & & 0.721 \\
\hline Feminine & $4352(48.4)$ & $795(49.1)$ & \\
\hline Masculine & $4639(51.6)$ & $823(50.9)$ & \\
\hline \multicolumn{4}{|l|}{ Birth weight (grams) } \\
\hline Mean $( \pm)$ SD & $3282.6 \pm 439.1$ & $3292 \pm 451.3$ & 0.407 \\
\hline$<2500$ & $271(3.0)$ & $57(3.5)$ & \\
\hline$[2500-3799]$ & $7649(85.1)$ & $1334(82.4)$ & 0.027 \\
\hline$\geq 3800$ & $1072(11.9)$ & $227(14.0)$ & \\
\hline SGA $<10^{\text {th }}$ percentile & $1011(11.2)$ & $202(12.5)$ & 0.148 \\
\hline \multicolumn{4}{|l|}{ pH at ombilical cord } \\
\hline$<7.10$ & $116(1.3)$ & $24(1.5)$ & 0.550 \\
\hline$<7.00$ & $19(0.2)$ & $2(0.1)$ & 0.459 \\
\hline \multicolumn{4}{|l|}{ Respiratory resuscitation } \\
\hline Ventilatory assistance & $476(5.3)$ & $115(7.1)$ & 0.003 \\
\hline Mask ventilation & $294(3.3)$ & $67(4.1)$ & 0.075 \\
\hline Nasal ventilation & $31(0.3)$ & $11(0.7)$ & 0.048 \\
\hline Continuous positive pressure & $99(1.1)$ & $25(1.5)$ & 0.126 \\
\hline Tracheal intubation & $117(1.3)$ & $34(2.1)$ & 0.012 \\
\hline Neonatal death in labor ward & $0(0)$ & $1(0.06)^{*}$ & - \\
\hline
\end{tabular}

SGA : small for gestational age 
Appendix A.1: Subgroup analysis: maternal, pregnancy and labor characteristics

\begin{tabular}{|c|c|c|c|}
\hline & $\begin{array}{c}<35 \text { years } \\
\mathbf{N}=\mathbf{8 9 9 3} \\
\mathrm{n}(\%)\end{array}$ & $\begin{array}{c}\geq 40 \text { years } \\
\mathbf{N}=\mathbf{3 6 7} \\
\mathrm{n}(\%)\end{array}$ & $\mathbf{P}$ \\
\hline \multicolumn{4}{|l|}{ Maternal characteristics } \\
\hline \multicolumn{4}{|l|}{ Age (years) } \\
\hline Mean \pm SD & $28.2 \pm 3.8$ & $42.1 \pm 2.6$ & $<0.001$ \\
\hline \multicolumn{4}{|l|}{ Body mass index before delivery $\left(\mathrm{kg} / \mathrm{m}^{2}\right)$} \\
\hline Mean \pm SD & $22.1 \pm 4.1$ & $22.9 \pm 4.3$ & $<0.001$ \\
\hline$<18,5$ & $1149(13.6)$ & $30(8.4)$ & \multirow{4}{*}{0.006} \\
\hline$[18.5-24]$ & $5606(66.2)$ & $238(66.7)$ & \\
\hline$[25-29]$ & $1232(14.5)$ & $59(16.5)$ & \\
\hline$\geq 30$ & $478(5.6)$ & $30(8.4)$ & \\
\hline \multicolumn{4}{|l|}{ Weight gain $(\mathrm{kg})$} \\
\hline Mean \pm SD & $12.7 \pm 5.8$ & $11.5 \pm 5.3$ & $<0.001$ \\
\hline$<9$ & $1224(19.3)$ & $78(26.3)$ & \\
\hline$[9-11]$ & $1394(21.9)$ & $74(25.0)$ & 0.001 \\
\hline$\geq 12$ & $3737(58.8)$ & $144(48.6)$ & \\
\hline Smoker & $1294(14.4)$ & $61(16.6)$ & 0.004 \\
\hline Chronic hypertension & $65(0.7)$ & $9(2.4)$ & $<0.001$ \\
\hline Diabetus mellitus & $70(0.8)$ & $6(1.6)$ & 0.073 \\
\hline \multicolumn{4}{|l|}{ Characteristics of current pregnancy } \\
\hline In vitro fertilisation & $271(3.0)$ & $80(20.8)$ & $<0.001$ \\
\hline Gestational diabetes & $277(3.1)$ & $33(9)$ & $<0.001$ \\
\hline Hypertensive gestational diseases & $206(2.3)$ & $22(6)$ & $<0.001$ \\
\hline Preterm labour & $649(7.2)$ & $30(8.2)$ & 0.488 \\
\hline Premature rupture of membrane & $82(0.9)$ & $6(1.6)$ & 0.159 \\
\hline Prenatal corticotherapy & $373(4.1)$ & $13(3.5)$ & 0.567 \\
\hline Supected intrauterine growth restriction & $26(0.3)$ & 0 & 0.302 \\
\hline Suspected macrosomia & $546(7.1)$ & $25(7.6)$ & 0.699 \\
\hline \multicolumn{4}{|l|}{ Labor characteristics } \\
\hline \multicolumn{4}{|l|}{ Gestational age at delivery (weeks) } \\
\hline Mean \pm SD & $39.9 \pm 1.2$ & $40.2 \pm 1.2$ & $<0.001$ \\
\hline $370 / 7-386 / 7$ & $1859(20.7)$ & $59(16.1)$ & $<0.001$ \\
\hline $390 / 7-406 / 7$ & $5279(58.7)$ & $189(51.5)$ & \\
\hline $410 / 7-416 / 7$ & $1583(17.6)$ & $94(25.6)$ & \\
\hline$\geq 420 / 7$ & $272(3.0)$ & $25(6.8)$ & \\
\hline \multicolumn{4}{|l|}{ Cervical dilation at first examination } \\
\hline Mean \pm SD & $3.2 \pm 1.4$ & $3.1 \pm 1.4$ & 0.499 \\
\hline Median (Q1-Q3) & $3(2-3)$ & $3(2-3)$ & 0.175 \\
\hline Peridural anesthesia & $7818(86.9)$ & $327(89.1)$ & 0.226 \\
\hline \multicolumn{4}{|c|}{ Cervical dilation at pose of peridural anesthesia $(\mathrm{cm})$} \\
\hline Mean \pm SD & $4.2 \pm 1.8$ & $4.0 \pm 1.8$ & 0.310 \\
\hline Median (Q1-Q3) & $4(3-5)$ & $4(3-5)$ & 0.191 \\
\hline Oxytocin use & $4810(53.5)$ & $197(53.7)$ & 0.942 \\
\hline \multicolumn{4}{|l|}{ Maximal oxytocin dose (UI) } \\
\hline Mean \pm SD & $38.3 \pm 24.1$ & $39.4 \pm 23.6$ & 0.516 \\
\hline Median (Q1-Q3) & $30(20-50)$ & $30(20-50)$ & 0.432 \\
\hline
\end{tabular}


Amniotic fluid color

Clear

Tainted

Meconial

Manual rotation
$6903(77.2) \quad 282(78.3)$

$1423(15.9) \quad 57(15.8)$

$617(6.9) \quad 21(5.9)$

$878(9.8) \quad 33(9)$
0.729

0.879 
Appendix A.2: Subgroup analysis: delivery characteristics

\begin{tabular}{|c|c|c|c|}
\hline & $\begin{array}{c}<35 \text { years } \\
\mathbf{N}=\mathbf{8 9 9 3} \\
\mathrm{n}(\%)\end{array}$ & $\begin{array}{c}\geq \mathbf{4 0} \text { years } \\
\mathbf{N}=\mathbf{3 6 7} \\
\mathrm{n}(\%)\end{array}$ & $\mathbf{P}$ \\
\hline Delivery mode & & & 0.810 \\
\hline Vaginal & $8026(89.2)$ & $329(89.6)$ & \\
\hline Caesarian section & $967(10.7)$ & $38(10.3)$ & \\
\hline \multicolumn{4}{|l|}{ Caesarian section } \\
\hline Indications & & & 0.485 \\
\hline Abnormal fetal heart rate & $389(40.2)$ & $19(50.0)$ & \\
\hline Arrest of labor & $547(56.6)$ & $18(47.4)$ & \\
\hline Others & $31(3.2)$ & $1(2.6)$ & \\
\hline \multicolumn{4}{|l|}{ Cervical dilation at $\mathrm{CS}(\mathrm{cm})$} \\
\hline Mean \pm SD & $6.1 \pm 2.5$ & $5.9 \pm 2.3$ & 0.715 \\
\hline Median (Q1-Q3) & $6(4-8)$ & $5.5(4-7)$ & 0.610 \\
\hline \multicolumn{4}{|l|}{ Labor duration (minutes) } \\
\hline \multicolumn{4}{|l|}{ Total labor } \\
\hline Mean \pm SD & $430.8 \pm 220.1$ & $426.9 \pm 214.1$ & 0.733 \\
\hline Median (Q1-Q3) & $422(274-570)$ & $410.5(283-556)$ & 0.749 \\
\hline \multicolumn{4}{|l|}{ Latent phase } \\
\hline Mean \pm SD & $191.9 \pm 131.9$ & $189.1 \pm 132.7$ & 0.707 \\
\hline Median (Q1-Q3) & $182.5(84-275)$ & $165(90-270)$ & 0.511 \\
\hline \multicolumn{4}{|l|}{ Active phase } \\
\hline Mean \pm SD & $150.1 \pm 110.4$ & $145.2 \pm 103.7$ & 0.422 \\
\hline Median (Q1-Q3) & $125(70-201)$ & $117.5(60-200)$ & 0.338 \\
\hline \multicolumn{4}{|l|}{ Second phase } \\
\hline Mean \pm SD & $55.3 \pm 57.3$ & $57.7 \pm 57.9$ & 0.449 \\
\hline Median (Q1-Q3) & $40(0-110)$ & $45(0-115)$ & 0.363 \\
\hline \multicolumn{4}{|l|}{ Vaginal delivery } \\
\hline \multicolumn{4}{|l|}{ Total labor duration (minutes) } \\
\hline Mean \pm SD & $421.6 \pm 213.6$ & $416.1 \pm 209.5$ & 0.645 \\
\hline Median (Q1-Q3) & $414(271-557)$ & $405.5(278-536)$ & 0.546 \\
\hline \multicolumn{4}{|l|}{ Latent phase duration (minutes) } \\
\hline Mean \pm SD & $191.9 \pm 131.9$ & $189.1 \pm 132.7$ & 0.707 \\
\hline Median (Q1-Q3) & $182.5(84-275)$ & $165(90-270)$ & 0.511 \\
\hline \multicolumn{4}{|l|}{ Active phase duration (minutes) } \\
\hline Mean \pm SD & $150.1 \pm 110.4$ & $145.2 \pm 103.7$ & 0.422 \\
\hline Median (Q1-Q3) & $125(70-201)$ & $117.5(60-200)$ & 0.338 \\
\hline \multicolumn{4}{|l|}{ Second phase duration (minutes) } \\
\hline Mean \pm SD & $55.3 \pm 57.3$ & $57.7 \pm 57.9$ & 0.449 \\
\hline Median (Q1-Q3) & $40(0-110)$ & $45(0-115)$ & 0.363 \\
\hline Operative vaginal delivery & $3368(42.0)$ & $149(45.3)$ & 0.231 \\
\hline Indications & & & 0.525 \\
\hline Abnormal cardiac fotal rate & $1904(57.0)$ & $90(61.6)$ & \\
\hline Slow progression & $1433(42.9)$ & $56(38.4)$ & \\
\hline Other & $2(0.1)$ & 0 & \\
\hline Third or fourth perineal laceration & $23(0.3)$ & $1(0.3)$ & 0.942 \\
\hline
\end{tabular}

Postpartum complications 


\begin{tabular}{lccc} 
Postpartum hemorrhage & $358(4)$ & $16(4.4)$ & 0.716 \\
Blood transfusion & $118(1.3)$ & $8(2.2)$ & 0.157 \\
Nalador & $317(3.5)$ & $14(3.8)$ & 0.768 \\
Uterine arteries embolisation & $2(0.02)$ & 0 & 0.775 \\
Vascular ligation & $2(0.02)$ & $1(0.3)$ & 0.009 \\
Compressive uterine sutures & $11(0.1)$ & $1(0.3)$ & 0.431 \\
Hysterectomy & $0(0)$ & $0(0)$ & - \\
\hline
\end{tabular}


Appendix A.3: Subgroup analysis: neonatal outcomes

\begin{tabular}{|c|c|c|c|}
\hline & $\begin{array}{c}<35 \text { years } \\
\mathbf{N}=8993 \\
\mathrm{n}(\%)\end{array}$ & $\begin{array}{c}\geq 40 \text { years } \\
\mathbf{N}=\mathbf{3 6 7} \\
\mathrm{n}(\%)\end{array}$ & $\mathbf{P}$ \\
\hline Gender & & & 0,905 \\
\hline Feminine & $4352(48,4)$ & $181(49,3)$ & \\
\hline Masculine & $4639(51,6)$ & $186(50,7)$ & \\
\hline \multicolumn{4}{|l|}{ Birth weight (grams) } \\
\hline Mean \pm SD & $3282,6 \pm 439,1$ & $3270 \pm 447,3$ & 0,783 \\
\hline$<2500$ & $271(3,0)$ & $13(3,5)$ & \\
\hline [2500-3799] & $7649(85,1)$ & $308(83,9)$ & 0,027 \\
\hline$\geq 3800$ & $1072(11,9)$ & $46(12,5)$ & \\
\hline SGA $<10$ th percentile & $1011(11,2)$ & $53(14,4)$ & 0,058 \\
\hline \multicolumn{4}{|l|}{ pH at ombilical cord } \\
\hline$<7.10$ & $116(1,3)$ & $4(1,1)$ & 0,737 \\
\hline$<7.00$ & $19(0,2)$ & 0 & 0,378 \\
\hline \multicolumn{4}{|l|}{ Respiratory resuscitation } \\
\hline Ventilatory assistance & $476(5,3)$ & $33(9)$ & 0,002 \\
\hline Mask ventilation & $294(3,3)$ & $20(5,4)$ & 0,023 \\
\hline Nasal ventilation & $31(0,3)$ & $2(0,5)$ & 0,526 \\
\hline Continuous positive pressure & $99(1,1)$ & $7(1,9)$ & 0,152 \\
\hline Tracheal intubation & $117(1,3)$ & $9(2,4)$ & 0,061 \\
\hline Neonatal death in labor ward & $0(0)$ & $0(0)$ & - \\
\hline
\end{tabular}

